\title{
Validity of Electronic Device-Based Application for Visual Acuity Examination: A Systematic Review
}

\author{
Natasya F. Yulianti ${ }^{1}$, Al Munawir ${ }^{2}$, and Novan K. Adji ${ }^{3}$ \\ ${ }^{1}$ Faculty of Medicine, University of Jember, Jember, 68121 Indonesia \\ ${ }^{2}$ Department of Pathology, Faculty of Medicine, University of Jember, Jember, 68121 Indonesia \\ ${ }^{3}$ Departement of Neurosurgery, Soebandi General Hospital, Jember, 68111 Indonesia \\ Corresponding author: Al Munawir (e-mail: almunawir.fk@unej.ac.id).
}

\begin{abstract}
Recent years, advances in the internet and communication technology have enabled the proliferation of digital medical devices with innovations in the form of health applications, including for visual acuity examination. However, the validity of these applications remains unclear. The limited mobility and health service during the COVID-19 pandemic underscores the urgent need to conduct research that validates these electronic device-based applications. Thus, this study aims to critically analyze whether the electronic device-based application is able to provide a valid and high-quality visual acuity examination. A systematic review was conducted through studies search on PubMed, MEDLINE, Springer, and Cochrane Library using specific keywords. After the studies were selected through inclusion and exclusion criteria, extraction was carried out. Publications from 2011 to the end of 2021 were reviewed, yielding in 1409 studies, of which 19 were included. The results showed a lower systematic bias for distance visual acuity testing with electronic device-based applications compared to standard reference tests with a mean difference of -0.08 to $0.10 \log$ MAR. The validity of the near visual acuity examination with the application shows better results than the distance examination which is marked by smaller $95 \%$ limits of agreement range. The results of the analysis of Bland-Altman plots in all the studies reviewed showed that the accuracy of the examination results tended to increase in patients who had better visual acuity. In practice, the use of electronic device-based applications for visual acuity examination can increase the work effectiveness of medical personnel and the proliferation of digital medical devices. It can also be one of the breakthroughs in the field of remote medical services and support the implementation of telemedicine policies.
\end{abstract}

INDEX TERMS Application, electronic device, visual acuity, systematic review

\section{INTRODUCTION}

Recent years, electronic devices have become an integral part of our lives. The number of smartphone users in 2016 was more than seven billion users worldwide. The rate of internet users also increased globally by about 7 -fold from $6.5 \%$ to $43 \%$ between 2000 and 2015. In 2015, the rate of households with internet access also increased from $18 \%$ in 2005 to $46 \%$ in 2015 [1]. The advances of the internet and communication technology have enabled the proliferation of digital medical devices with innovations in the form of health applications. Health applications currently cover various fields, one of them is the application of visual acuity examination. This promising approach can help overcome accessibility problems by using electronic devices such as smartphones, tablets, and computers that can be used independently from home, as well as in the clinic [2].

The examination of visual acuity using a computer was first investigated by Michael Bach in 1996. The results showed that there were limitations to image elements or pixels on a computer monitor, so that only certain visual acuity could be tested, at a distance of five meters [3]. Computerized examinations in the following years showed that computerized 
systems allowed early detection of true clinical changes in visual acuity in each patient [4]

Visual acuity is a measure of the eye's ability to clearly distinguish the shape and detail of objects at a certain distance [5]. Visual acuity examination is done by comparing a person's visual acuity with the standard normal person which usually begins with an examination using an optotype. Optotypes are marks of different sizes that are placed systematically on a visual acuity chart. The optotype is usually a number, letter, or symbol as an instrument to test visual acuity [6]. Conventionally, symbols have been printed on cards or graphics that are mounted on walls and presented to patients for examination [5].

Human visual acuity can change due to many eye problems, therefore an examination of visual acuity needs to be carried out to help in detecting various eye disorders. Eye disorder such as visual impairment is a health problem that has profound effects on quality of life, educational attainment, and economic productivity $[7,8]$.

World Health Organization (WHO) estimates that 2.2 billion people in the world have near or distance vision problems. The most common causes of visual impairment worldwide are uncorrected refractive errors (48.99\%), followed by cataracts $(25.81 \%)$ and age-related macular degeneration (4.1\%). Meanwhile, the most common causes of blindness were cataracts $(34.47 \%)$, followed by uncorrected refractive errors $(20.26 \%)$, and glaucoma $(8.30 \%)$. More than $75 \%$ of visual impairments are actually preventable [9]. Nationally, the results of the 2014-2016 Rapid Assessment of Avoidable Blindness (RABB) survey in 15 provinces showed that the blindness rate in Indonesia reached 900,000 people. The main cause of blindness and visual impairment in the population aged over 50 years in Indonesia is untreated cataracts with a proportion of $77.7 \%$ [10]. This shows that there are still many cases that are not corrected or even undetected. This fact shows the importance of increasing the affordability of visual acuity examinations to assist in the early detection of visual impairment.

During the COVID-19 pandemic, social distancing, quarantine, and restrictions on face-to-face interactions were enforced to prevent and break the spread of the SARS-CoV-2 virus. This poses a challenge in providing eye care to patients, as eye examinations require the examiner to be in close contact with the patient. In fact, the first case of COVID-19 was reported by an ophthalmologist at the Wuhan Central Hospital, who also died from the new virus $[11,12]$.

Various types of visual acuity testing applications are available and can be downloaded easily on the internet. However, the validity of these applications remains unclear. Meanwhile, the limited mobility and health service during the COVID-19 pandemic underscore the urgent need to conduct research that validates these electronic device-based applications. Thus, this study aims to critically analyze whether the electronic device-based application is able to provide a valid and high-quality visual acuity examination.

\section{MATERIALS AND METHODS}

\section{A. SEARCH STRATEGY}

This systematic review is conducted based on Preferred Reporting Items for Systematic Review and Meta-analysis (PRISMA) guidelines. We performed a comprehensive search of PubMed, MEDLINE, Springer, and Cochrane Library databases up to January 2011 and updated later to the end of 2021 using keywords as follows: "application", "electronic device", and "visual acuity". Boolean operators (AND, OR, NOT) and truncation $(*)$ were applied to broaden and narrow the search results. We also used the Medical Subject Headings (MeSH) terms in the search strategy. However, the search language was limited to English and Bahasa Indonesia.

\section{B. ELIGIBILITY CRITERIA}

Inclusion criteria were set to filter the results as follows: (1) diagnostic test, observational study, or clinical trial, and (2) investigating the validity of visual acuity examination performed by electronic device-based application. It is worth mentioning that different study designs were incorporated into this review including those with one or more index tests and with any reference method that investigated visual acuity test in the general population. Conversely, the exclusion criteria defined included: (1) irrelevant topics, (2) not having index test as comparison, (3) unknown and/or inappropriate study types and settings, (4) incompatible language, and (5) irretrievable full-text articles.

\section{DATA EXTRACTION AND RISK OF BIAS}

The following data from articles were extracted, including author and year of publication, study design and location, sample size, index test, reference test, and outcome measures such as mean difference, sensitivity, specificity, and any other reported outcome. The quality of included studies was assessed using the Joanna Briggs Institute (JBI) checklist with $\geq 50 \%$ cut-off. Risk of bias assessment was conducted by the reviewers collaboratively and discrepancies were resolved by consensus between reviewers.

\section{RESULTS}

\section{A. STUDY SELECTION}

A total of 1409 studies were initially identified. After removing 324 duplicates, 1085 results were screened based on title and abstract, out of which 132 full texts were identified to be examined (Figure-1). Finally, 113 studies were excluded due to not meeting the inclusion criteria. In total, 19 articles 
were included in this review. The quality assessment of all studies using the JBI checklist showed a low risk of bias.

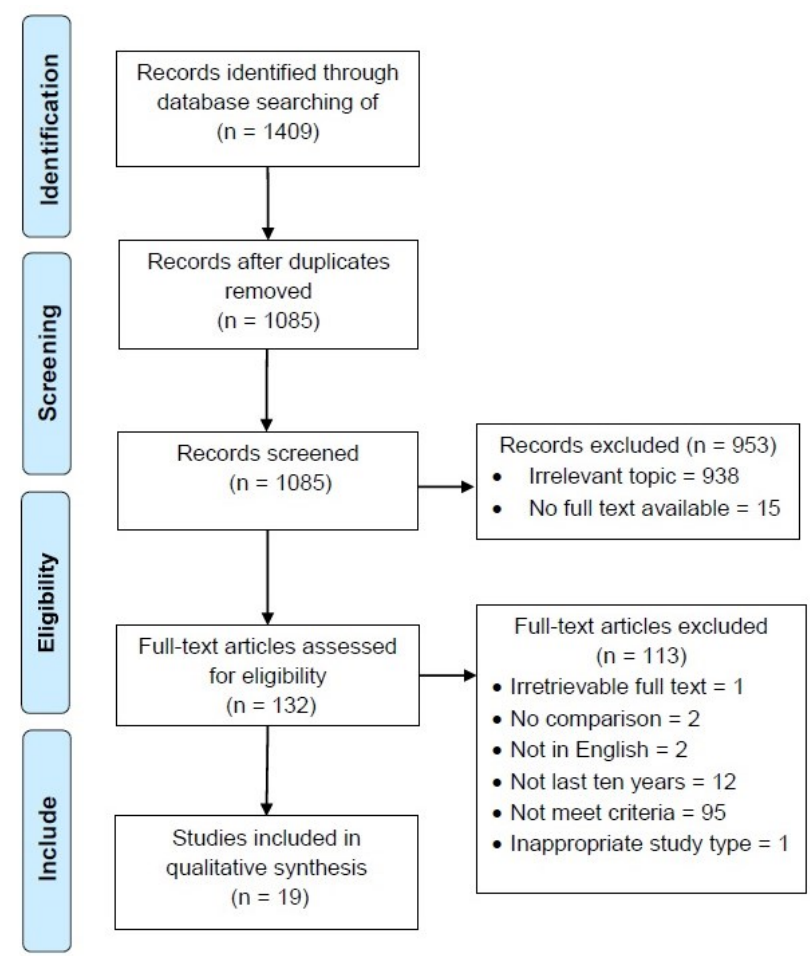

FIGURE 1. Flowchart diagram of the literature search strategy

\section{B. STUDY CHARACTERISTICS}

The general characteristics of the selected studies are summarized in Table-1. Thirteen out of nineteen selected studies had a diagnostic study design. Four was a crosssectional study $[14,18,21,26]$ and two studies were RCT $[17,22]$. These studies had been published from 2011 to 2021 with worldwide distribution, including USA, Kenya, Australia, Malaysia, India, Thailand, UK, Netherland, China, France, and Canada. Briefly, these studies have included 23,805 population samples. The mean age of the subjects was between 3 to 97 years old. Except for four studies [24, 29-31], gender distribution was described in all studies [13-31]. Most of the studies were validation tests in controlled environments.

\section{DISCUSSION}

The results showed 18 of 19 studies stated that visual acuity examination with electronic device-based applications gave valid results. The overall identification results also show lower mean difference between digital applications compared to standard reference tests in assessing distance visual acuity. This indicates a low systematic bias. The mean difference ranged from -0.08 to $0.10 \log$ MAR. The majority of the $95 \%$ limits of agreement range on the results of the distance visual acuity examination is quite wide, which indicates the variability.
The study by Satgunam et al. (2021) stated that the Smart Optometry application was not comparable to the reduced Snellen chart, but was declared valid because it only differed by $2 \operatorname{logMAR}$ lines, which means it is still clinically acceptable. This difference is not a problem when digital applications are used for screening to detect visual impairments associated with decreased visual acuity, even though age and refractive errors affect measurements in Smart Optometry applications [13].

Several studies have attempted to link the use of electronic device-based applications to clinical practice. A study stated that the repeatability of using the Eye Chart application needs to be investigated before being integrated into clinical practice even though the study results are reported to be valid [16]. Correspondingly, the study by Perera et al. (2015) has valid results but still needs further research for clinical use [28]. Different things were reported in a previous study by Gounder et al. (2014) who stated that the Eye Snellen application can be used to measure visual acuity in clinical settings reliably on all measures of visual acuity [30]. More specifically, in one application, Eye Chart Pro, it was reported to be reliable for testing if Snellen's visual acuity was better than 20/200 or 0.1 in decimal [31]. The results of the analysis of Bland-Altman plots in all the studies reviewed did show that the accuracy of the examination results tended to increase in patients who had better visual acuity.

In contrast to the results of other studies, one study stated that the Eye Hand Book application was invalid. The application provides an overestimated close-range visual acuity result compared to a conventional near card with an average of $0.11 \log$ MAR, except for the standard measurement result of 20/20. This means that patients tend to perform better on examinations, so eye disorders may go undetected. Overestimated results can result in delays in treatment. This study suspects that the main factor that plays a role in the discrepancy in the results between the application and the standard reference test is the contrast ratio. The contrast ratio of the clean printed Snellen chart or ETDRS is below 33:1, while the iPhone 5 as a digital device used in this study has a contrast ratio of 1151:1 [27]. Other studies have also reported that measurements of visual acuity in subjects can be overestimated with increasing contrast and lighting levels [32]. However, the validity of the near vision test in this systematic review overall shows better results than the remote visual acuity assessment which is characterized by a smaller $95 \%$ limit of agreement range. In daily use in clinics, examination time is critical for efficiency. 
TABLE

DATA EXTRACTION

\begin{tabular}{|c|c|c|c|c|c|c|}
\hline Author, year & $\begin{array}{l}\text { Design, } \\
\text { location }\end{array}$ & Sample size & $\begin{array}{c}\text { Application, } \\
\text { electronic device }\end{array}$ & Index optotype & $\begin{array}{c}\text { Reference } \\
\text { optotype }\end{array}$ & Outcome \\
\hline \multirow[b]{2}{*}{$\begin{array}{l}\text { Satgunam et } \\
\text { al., } 2021[13]\end{array}$} & \multirow[b]{2}{*}{$\begin{array}{l}\text { Diagnostic } \\
\text { study, India }\end{array}$} & 68 participants & $\begin{array}{l}\text { Peek Acuity, } \\
\text { smartphone }\end{array}$ & $\begin{array}{l}\text { ETDRS } \\
\text { Tumbling }\end{array}$ & $\begin{array}{l}\text { COMPlog } \\
\text { presenting }\end{array}$ & Valid $(\mathrm{P}=0.3)$ \\
\hline & & 24 participants & $\begin{array}{l}\text { Smart Optometry, } \\
\text { smartphone }\end{array}$ & $\begin{array}{c}\mathrm{E} \\
\text { Tumbling E }\end{array}$ & $\begin{array}{l}\text { Tumbling E } \\
\text { Reduced Snellen } \\
\text { near vs chart with } \\
\text { tumbling E }\end{array}$ & $\begin{array}{c}\text { Valid (2 lines LogMAR } \\
\text { differences) }\end{array}$ \\
\hline $\begin{array}{l}\text { Tiraset et al., } \\
2021[14]\end{array}$ & $\begin{array}{l}\text { Cross- } \\
\text { Sectional, } \\
\text { Thailand }\end{array}$ & $\begin{array}{l}295 \text { eyes dari } 151 \\
\text { patiens }\end{array}$ & $\begin{array}{l}\text { Eye Chart, } \\
\text { smartphone }\end{array}$ & $\begin{array}{c}\text { Snellen } \\
\text { chart atau } \\
\text { Tumbling E }\end{array}$ & $\begin{array}{l}\text { ETDRS } \\
\text { chart }\end{array}$ & $\begin{array}{c}\text { Valid (OD: } \mathrm{ICC}=0,88 ; \\
\mathrm{p}<0,001, \text { OS: } \mathrm{ICC}=0,74 ; \\
\mathrm{p}<0,001)\end{array}$ \\
\hline $\begin{array}{l}\text { Hazari et al., } \\
2020[15]\end{array}$ & $\begin{array}{l}\text { Diagnostic } \\
\text { study, } \\
\text { Canada }\end{array}$ & $\begin{array}{c}25 \text { patiens normal, } \\
26 \text { patiens visus } \\
\text { menurun }\end{array}$ & Eye Chart Pro, iPad & ETDRS Chart & ETDRS Chart & $\begin{array}{c}\text { Valid (Mean diff logMAR }= \\
0.11 ; \mathrm{p}=0.82)\end{array}$ \\
\hline $\begin{array}{l}\text { Ansell et al., } \\
2020[16]\end{array}$ & $\begin{array}{l}\text { Diagnostic } \\
\text { study, } \\
\text { Australia } \\
\end{array}$ & $\begin{array}{l}24 \text { eyes in } 24 \\
\text { participants } \\
\text { (monocular) }\end{array}$ & $\begin{array}{l}\text { Eye Chart, } \\
\text { smartphone }\end{array}$ & Snellen chart & ETDRS chart & $\begin{array}{c}\text { Valid (Snellen: } 0.09 \\
\text { logMAR; ETDRS: } 0.08 \\
\text { logMAR) } \\
\end{array}$ \\
\hline $\begin{array}{l}\text { Wisse et al., } \\
2019 \text { [17] }\end{array}$ & RCT, UK & $\begin{array}{c}200 \text { eyes from } 100 \\
\text { participants }\end{array}$ & $\begin{array}{l}\text { Easee, smartphone } \\
\text { and computer }\end{array}$ & $\begin{array}{c}\text { Tumbling E dan } \\
\text { tool specific } \\
\text { optotypes } \\
\end{array}$ & ETDRS chart & Valid $(\mathrm{ICC}=0.92 ; \mathrm{P}=0.21)$ \\
\hline $\begin{array}{l}\text { Han et al., } \\
2019 \text { [18] }\end{array}$ & $\begin{array}{l}\text { Cross- } \\
\text { Sectional, } \\
\text { China and } \\
\text { Australia }\end{array}$ & 326 participants & $\begin{array}{l}\text { Vision at home, } \\
\text { smartphone }\end{array}$ & Tumbling E & $\begin{array}{l}\text { ETDRS tumbling E } \\
\text { and ETDRS near } \\
\text { chart }\end{array}$ & $\begin{array}{c}\text { Valid (Mean diff }-0.010- \\
0.100 \log \text { MAR) }\end{array}$ \\
\hline $\begin{array}{l}\text { Brucker et al., } \\
2019 \text { [19] }\end{array}$ & $\begin{array}{l}\text { Diagnostic } \\
\text { study }\end{array}$ & $\begin{array}{c}120 \text { eyes in } 78 \\
\text { participants }\end{array}$ & $\begin{array}{l}\text { Odysight, } \\
\text { smartphone }\end{array}$ & $\begin{array}{c}\text { ETDRS } \\
\text { Tumbling } \\
\text { E }\end{array}$ & $\begin{array}{c}\text { Sloan ETDRS } \\
\text { chart and ETDRS } \\
\text { chart }\end{array}$ & $\begin{array}{c}\text { Valid (Mean diff }-0.53- \\
1.53 \text { letters) }\end{array}$ \\
\hline $\begin{array}{l}\text { Zhao et al., } \\
2019 \text { [20] }\end{array}$ & $\begin{array}{l}\text { Cross } \\
\text { Sectional, } \\
\text { USA } \\
\end{array}$ & 108 participants & $\begin{array}{l}\text { Peek Acuity, } \\
\text { smartphone }\end{array}$ & $\begin{array}{c}\text { ETDRS } \\
\text { Tumbling E }\end{array}$ & Snellen eye chart & $\begin{array}{l}\text { Valid (Sensitivity 83\%- } \\
86 \% \text {; Specificity 70\%) }\end{array}$ \\
\hline $\begin{array}{l}\text { Nik Azis et al., } \\
2019 \text { [21] }\end{array}$ & $\begin{array}{l}\text { Cross- } \\
\text { Sectional, } \\
\text { Malaysia } \\
\end{array}$ & $\begin{array}{c}390 \text { eyes in } 195 \\
\text { patients }\end{array}$ & $\begin{array}{l}\text { AAPOS Vision } \\
\text { Screening, iPad }\end{array}$ & LEA Symbols & $\begin{array}{l}\text { ETDRS lightbox } \\
\text { with the LEA } \\
\text { symbols chart }\end{array}$ & $\begin{array}{l}\text { Valid (Sensitivity } 86,6 \% \\
\text { Specificity } 78.9 \% \text { ) }\end{array}$ \\
\hline $\begin{array}{l}\text { Rono et al., } \\
2018 \text { [22] }\end{array}$ & RCT, Kenya & $\begin{array}{l}10.579 \text { in Peek } \\
\text { group and } 10.284 \\
\text { in standard group }\end{array}$ & $\begin{array}{l}\text { Peek Acuity, } \\
\text { smartphone }\end{array}$ & $\begin{array}{c}\text { ETDRS } \\
\text { Tumbling E }\end{array}$ & $\begin{array}{c}\text { Snellen's } \\
\text { TumblingE chart }\end{array}$ & $\begin{array}{c}\text { Valid (Sensitivity } 77 \% \text { vs } \\
75 \% \text {; Specificity } 91 \% \text { vs } \\
97,4 \% \text { ) }\end{array}$ \\
\hline $\begin{array}{c}\text { Calabrese et } \\
\text { al, } 2018[23]\end{array}$ & $\begin{array}{l}\text { Diagnostic } \\
\text { study, USA }\end{array}$ & $\begin{array}{c}165 \text { (normal } \\
\text { vision) and } 43 \text { (low } \\
\text { vision) }\end{array}$ & $\begin{array}{l}\text { MNREAD iPad app, } \\
\text { iPad }\end{array}$ & MNREAD chart & $\begin{array}{c}\text { Printed MNREAD } \\
\text { chart }\end{array}$ & $\begin{array}{c}\text { Valid (Mean diff } 0.03 \\
\text { logMAR) }\end{array}$ \\
\hline $\begin{array}{c}\text { Pathipati et al., } \\
2016[24]\end{array}$ & $\begin{array}{l}\text { Diagnostic } \\
\text { study, USA }\end{array}$ & $\begin{array}{c}\text { Phase } 1: 57 \text { eyes in } \\
30 \text { patients, Phase } \\
2: 51 \text { eyes in } 17 \\
\text { patients }\end{array}$ & $\begin{array}{l}\text { Paxos Checkup by } \\
\text { Sightbook, } \\
\text { smartphone and } \\
\text { tablet } \\
\end{array}$ & $\begin{array}{c}\text { Tool-specific } \\
\text { optotypes }\end{array}$ & $\begin{array}{l}\text { Phase 1: Snellen } \\
\text { chart, Phase 2: } \\
\text { Rosenbaum near } \\
\text { card }\end{array}$ & $\begin{array}{l}\text { Valid (Mean diff } 0.15 \\
\operatorname{logMAR;} p=0.046)\end{array}$ \\
\hline $\begin{array}{l}\text { Bastawrous et } \\
\text { al., } 2015[25]\end{array}$ & $\begin{array}{c}\text { Diagnostic } \\
\text { study, Kenya }\end{array}$ & $\begin{array}{c}544 \text { eyes, } 300 \\
\text { patients }\end{array}$ & $\begin{array}{l}\text { Peek Acuity, } \\
\text { smartphone }\end{array}$ & $\begin{array}{c}\text { ETDRS } \\
\text { Tumbling E }\end{array}$ & $\begin{array}{l}\text { ETDRS tumbling E } \\
\text { chart and Snellen } \\
\text { chart }\end{array}$ & $\begin{array}{c}\text { Valid (Mean diff } 0,07 \\
(95 \% \text { CI: } 0,05-0,09) \text { and } \\
0,08 \text { (95\% CI: } 0,06-0,10) \\
\text { logMAR }\end{array}$ \\
\hline $\begin{array}{l}\text { Jan-Bond et } \\
\text { al., } 2015 \text { [26] }\end{array}$ & $\begin{array}{l}\text { Cross- } \\
\text { Sectional, } \\
\text { Malaysia }\end{array}$ & $\begin{array}{l}101 \text { patients and } \\
\text { staff }\end{array}$ & $\begin{array}{c}\text { Rapid Eye Screening } \\
\text { Test / REST, } \\
\text { smartphone }\end{array}$ & $\begin{array}{l}\text { Tumbling E } \\
\text { chart }\end{array}$ & $\begin{array}{l}\text { ETDRS tumbling E } \\
\text { chart }\end{array}$ & $\begin{array}{c}\text { Valid (OD: } \mathrm{r}=0.829 ; \mathrm{OS}: \mathrm{r} \\
=0.871 ; \mathrm{p}<0.001 ; 95 \% \\
\mathrm{loA} \pm 0.11(\mathrm{OD}) \text { and } \pm 0.10 \\
(\mathrm{OS})\end{array}$ \\
\hline $\begin{array}{c}\text { Tofigh et al., } \\
2015 \text { [27] }\end{array}$ & $\begin{array}{l}\text { Diagnostic } \\
\text { study, USA }\end{array}$ & 50 patients & $\begin{array}{c}\text { Eye Hand Book, } \\
\text { smartphone }\end{array}$ & $\begin{array}{c}\text { Tool-specific } \\
\text { optotypes }\end{array}$ & $\begin{array}{l}\text { Rosenbaum near } \\
\text { card }\end{array}$ & Invalid \\
\hline $\begin{array}{l}\text { Perera et al., } \\
2015 \text { [28] }\end{array}$ & $\begin{array}{l}\text { Diagnostic } \\
\text { study, } \\
\text { Australia } \\
\end{array}$ & 80 patients & $\begin{array}{l}\text { Snellen DrBloggs } \\
\text { Ltd, smartphone }\end{array}$ & Snellen chart & Snellen chart & $\begin{array}{c}\text { Valid (Mean diff } 0.02 \\
\text { logMAR; } 95 \% \text { loA }=0,332 ; \\
0,372 \log \text { MAR) }\end{array}$ \\
\hline $\begin{array}{c}\text { Toner et al., } \\
2014 \text { [29] }\end{array}$ & $\begin{array}{l}\text { Diagnostic } \\
\text { study, USA }\end{array}$ & 60 patients & $\begin{array}{l}\text { Handy Eye Check, } \\
\text { tablet and computer }\end{array}$ & Handy eye chart & Handy eye chart & $\begin{array}{c}\text { Valid }(\mathrm{r}=0.92 ; \text { Mean diff - } \\
0.005 \text { logMAR; } 95 \% \text { loA }= \\
-0.003-0.02)\end{array}$ \\
\hline $\begin{array}{l}\text { Gounder et } \\
\text { al., } 2014[30]\end{array}$ & $\begin{array}{l}\text { Diagnostic } \\
\text { study, } \\
\text { Australia } \\
\end{array}$ & $\begin{array}{c}122 \text { eyes dari } 67 \\
\text { patients }\end{array}$ & $\begin{array}{c}\text { EyeSnellen, } \\
\text { smartphone and iPad }\end{array}$ & Snellen chart & Snellen light box & $\begin{array}{c}\text { Valid (Mean diff }-0.001 \\
\operatorname{logMAR} ; 95 \% \operatorname{loA}= \\
-0.169-0.171) \\
\end{array}$ \\
\hline $\begin{array}{l}\text { Zhang et al., } \\
2013 \text { [30] }\end{array}$ & $\begin{array}{c}\text { Diagnostic } \\
\text { study, China }\end{array}$ & $\begin{array}{c}240 \text { eyes, } 120 \\
\text { patients }\end{array}$ & Eye Chart Pro, iPad & Tumbling E & $\begin{array}{c}\text { Standard tumbling } \\
\text { E light box }\end{array}$ & $\begin{array}{c}\text { Valid }(\mathrm{P}=0.001 ; \text { Mean diff } \\
0.02 \log \mathrm{MAR})\end{array}$ \\
\hline
\end{tabular}

Accredited by Ministry of Research and Technology /National Research and Innovation Agency, Indonesia 
This is the reason why the Snellen chart is an optotype for routine examination in clinical practice. The results of the application quality analysis on the operability component show that the Peek Acuity application that uses the ETDRS Tumbling E chart optotype has an average inspection time of 5 seconds faster than the conventional ETDRS Tumbling E chart [24]. Correspondingly, the REST application also recorded an average examination time of 2.8 seconds faster than the standard reference test [26]. These results support digital applications for routine use. Nevertheless, previous research reported there is a slight delay between the time. During this delay, the subject may begin to read the first line of the text. The result would be an underestimate of the reading time, and consequently, an overestimate of reading speed. This possibility is supported by a recent study that compared stopwatch versus automated timing in a computer-based reading test [32].

In addition, visual acuity examination by application is also affected by the basis of the electronic device. Recent studies have reported few differences in test time between paper and screens 33,34 . In a different study, it is still a debate whether reading is better on paper or LCD [35]. Furthermore, previous research found that visual acuity examinations on iPads are particularly susceptible to glare. Utilizing an antiglare coating can be the solution [36]. However, some of the information that accompanies the valid statement decisions in 18 studies shows that the feasibility of digital applications is currently still limited to early detection and has the potential to be used as an initial examination in remote medical services.

Visual acuity examination with digital applications based on electronic devices has a lot of importance for the development of remote services. This makes various studies state recommendations for the use of digital applications even though there are slight differences between the results of the examination and the application compared to standard references. Conventional examinations in hospitals require the patient to physically come to the clinic. Difficulties that may be faced by patients are living far away, for example, people living in rural areas, elderly patients, and patients who are unable to move [37]. Remote inspection can also reduce costs and speed up early detection [38]. Moreover, a smart mobile application to monitor visual function in diabetic retinopathy and age-related macular degeneration patients already existed and is being investigated [39]. With the increasing flow of digitization, the portability aspect seen from instability supports the quality of digital visual acuity check applications.

The availability and increasing use of electronic devices, especially smartphones and tablets, further emphasizes the potential for digital applications to identify the most common causes of visual impairment in Indonesia and the world, including uncorrected refractive errors. Studies report that half of the visually impaired population actually has a decrease in visual acuity that can be prevented or corrected with glasses or contact lenses [40].

In practice, the use of electronic device-based applications for visual acuity examination can increase the work effectiveness of medical personnel and increase the proliferation of digital medical devices. The results of this systematic review can also be one of the breakthroughs in the field of remote medical services and support the implementation of telemedicine policies.

As in other studies, this review also has several limitations. Due to the novelty of the topic discussed, there are limited study resources. As a result, the study design and validity parameters of the included studies varied. However, all being considered large study using the electronic devicebased application as an index and conventional visual acuity examination as the comparison.

\section{v. CONCLUSION}

In conclusion, the use of electronic device-based applications provides valid results for early detection in visual acuity examinations. This systematic review also found that electronic device-based application visual acuity examination showed better results in near-range visual acuity assessments than the distance visual acuity assessments. We also found that the results of Bland-Altman plots analysis observed in all included studies showed that the accuracy of the examination results tended to increase in patients who had better visual acuity.

Further research on the repeatability of visual acuity examination with electronic device-based applications is required to support the validity conclusion. In addition, it is necessary to conduct research that examines the potential for remote medical services.

\section{ACKNOWLEDGMENT}

Not applicable.

\section{CONFLICT OF INTEREST}

The authors declare no conflict of interest

\section{REFERENCES}

[1] Parasuraman S, Sam AT, Yee SWK, Chuon BLC, Ren LY. "Smartphone Usage and Increased Risk of Mobile Phone Addiction: A Concurrent Study." International Journal of Pharmaceutical Investigation, vol. 7 , no. 3, 2017, pp. 125-31, doi:10.4103/jphi.JPHI 5617.

[2] Bates DW, Landman A, Levine DM. "Health Apps and Health Policy: What Is Needed?" JAMA, vol. 320, no. 19, 2018, pp. 1975-1976.

[3] Bach M. "The Freinburg Visual Acuity Test Automatic Measurement of Visual Acuity." Optometry and Vision Science, vol. 73, no. 1, 1996, pp. 49-53.

[4] Rosser D, Murdoch I, Fitzke F, Laidlaw D. "Improving on ETDRS Acuities: Desgin and Result for a Computerized Thresholding Device." British Journal of Opthalmology, vol. 17, no. 701, 2003, p. 6.

[5] Marsden J, Stevens S, Ebri A. "How to measure distance visual 
acuity." Community Eye Health, vol. 27, no. 85, 2014, p. 16.

[6] Bujger Z, Picman J, Lukenda A, Petricek I. "Standardisation of Optotypes." Lijecnicki Vjesnik, vol. 132, no. 7-8, 2010, pp. 252-256.

[7] Köberlein J, Beifus K, Schaffert C, Finger RP. "The Economic Burden of Visual Impairment and Blindness: A Systematic Review." BMJ Open, vol. 3, no. 11, 2013, p. e003471

[8] Hirneiss C. "The Impact of a Better-Seeing Eye and a Worse-Seeing Eye on Vision-Related Quality of Life." Clinical Ophthalmology, vol. 8, 2014, pp. 1703-1709.

[9] WHO. World Report on Vision. World Health Organization 2019. 2021.

[10] Ismandari F. Pusat Data Dan Informasi. Kementerian Kesehatan RI. 2018.

[11] Petersen E, Hui D, Hamer DH, et al. "Li Wenliang, a Face to the Frontline Healthcare Worker. The First Doctor to Notify the Emergence of the SARS-CoV-2, (COVID-19), Outbreak." International Journal of Infectious Diseases, vol. 93, 2020, pp. 205207, doi:https://doi.org/10.1016/j.ijid.2020.02.052.

[12] Anstice NS, Jacobs RJ, Simkin SK, Thomson M, Thompson B, Collins A V. "Do Picture-Based Charts Overestimate Visual Acuity? Comparison of Kay Pictures, Lea Symbols, HOTV and Keeler LogMAR Charts with Sloan Letters in Adults and Children." PloS One, vol. 12, no. 2, Feb. 2017, doi:10.1371/JOURNAL.PONE.0170839.

[13] Satgunam P, Thakur M, Sachdeva V, Reddy S, Rani PK. "Validation of Visual Acuity Applications for Teleophthalmology during COVID19. Indian Journal of Ophthalmology." Indian Journal of Ophthalmology, vol. 69, no. 2, 2021, pp. 385-390, doi:https://doi.org/10.4103/ijo.IJO 233320.

[14] Tiraset N, Poonyathalang A, Padungkiatsagul T, Deeyai M, Vichitkunakorn P, Vanikieti K. "Comparison of Visual Acuity Measurement Using Three Methods: Standard Etdrs Chart, near Chart and a Smartphone-Based Eye Chart Application." Clinical Ophthalmology, vol. $15, \quad 2021, \quad$ pp. 859-69, doi:10.2147/OPTH.S304272

[15] Hazari H, Curtis R, Eden K, Hopman WM, Irrcher I, Bona MD. "Validation of the Visual Acuity IPad App Eye Chart Pro Compared to the Standard Early Treatment Diabetic Retinopathy Study Chart in a Low-Vision Population." Journal of Telemedicine and Telecare, 2020, doi:10.1177/1357633X20960640

[16] Ansell K, Maconachie G, Bjerre A. "Does the Eyechart App for Iphones Give Comparable Measurements to Traditional Visual Acuity Charts?" British and Irish Orthoptic Journal, vol. 16, no. 1, 2020, pp. 19-24, doi:10.22599/bioj.146.

[17] Wisse RPL, Muijzer MB, Cassano F, Godefrooij DA, Prevoo YFDM, Soeters N. "Validation of an Independent Web-Based Tool for Measuring Visual Acuity and Refractive Error via the MORE (Manifest Versus Online Refractive Evaluation) Trial: Prospective Open-Label Noninferiority Clinical Trial." Journal of Medical Internet Research, vol. 21, no. 11, 2019, pp. 1-13, doi:10.2196/14808

[18] Han X, Scheetz J, Keel S, et al. "Development and Validation of a Smartphone-Based Visual Acuity Test (Vision at Home)." Translational Vision Science and Technology, vol. 8, no. 4, John Wiley \& Sons, Ltd., July 2019, doi:10.1002/CENTRAL/CN02011345.

[19] Brucker J, Bhatia V, Sahel JA, Girmens JF, Mohand-Saïd S "Odysight: A Mobile Medical Application Designed for Remote Monitoring - A Prospective Study Comparison with Standard Clinical Eye Tests." Ophthalmology and Therapy, vol. 8, no. 3, 2019, pp. 46176, doi:10.1007/s40123-019-0203-9.

[20] Zhao L, Stinnett SS, Prakalapakorn SG. "Visual Acuity Assessment and Vision Screening Using a Novel Smartphone Application." Journal of Pediatrics, vol. 213, Mosby Inc., Oct. 2019, pp. 203210.e1, doi:10.1016/j.jpeds.2019.06.021

[21] Nik Azis NN, Chew FLM, Rosland SF, Ramlee A, Che-Hamzah J. "Parents' Performance Using the AAPOS Vision Screening App to Test Visual Acuity in Malaysian Preschoolers." Journal of AAPOS, vol. 23, no. 5, 2019, pp. 268.e1-268.e6, doi:10.1016/J.JAAPOS.2019.01.019.
[22] Rono HK, Bastawrous A, Macleod D, et al. "Smartphone-Based Screening for Visual Impairment in Kenyan School Children: A Cluster Randomised Controlled Trial." The Lancet Global Health, vol. 6, no. 8, 2018, pp. e924-32, doi:10.1016/S2214-109X(18)30244-4.

[23] Calabrèse A, To L, He Y, Berkholtz E, Rafianm P, Legge GE. "Comparing Performance on the MNREAD IPad Application with the MNREAD Acuity Chart." Journal of Vision, vol. 18, no. 1, 2018, doi:10.1167/18.1.8.

[24] Pathipati AS, Wood EH, Lam CK, Sáles CS, Moshfeghi DM. "Visua Acuity Measured with a Smartphone App Is More Accurate than Snellen Testing by Emergency Department Providers." Graefe's Archive for Clinical and Experimental Ophthalmology, vol. 254, no. 6, Springer Verlag, June 2016, pp. 1175-80, doi:10.1007/S00417-0163291-4.

[25] Bastawrous A, Rono HK, Livingstone IA, et al. "Development and Validation of a Smartphone-Based Visual Acuity Test (Peek Acuity) for Clinical Practice and Community-Based Fieldwork." JAMA Ophthalmology, vol. 133, no. 8, American Medical Association, Aug. 2015, pp. 930-37,

[26] Jan-Bond C, Wee-Min T, Hong-Kee N, et al. "REST - An Innovative Rapid Eye Screening Test." Journal of Mobile Technology in Medicine, vol. 4, no. 3, 2015, pp. 20-25, doi:10.7309/jmtm.4.3.4.

[27] Tofigh S, Shortridge E, Elkeeb A, Godley BF. "Effectiveness of a Smartphone Application for Testing near Visual Acuity." Eye, vol. 29, no. 11, 2015, pp. 1464-68, doi:10.1038/EYE.2015.138.

[28] Perera C, Chakrabarti R, Islam FMA, Crowston J. "The Eye Phone Study: reliability and accuracy of assessing Snellen visual acuity using smartphone technology". no. 7, 2015, pp. 888-94, doi:10.1038/EYE.2015.60

[29] Toner KN, Lynn MJ, Candy TR, Hutchinson AK. "The Handy Eye Check: A Mobile Medical Application to Test Visual Acuity in Children." Journal of AAPOS, vol. 18, no. 3, 2014, pp. 258-60, doi:10.1016/j.jaapos.2014.01.011.

[30] Gounder PA, Cole E, Colley S, Hille DM. "Validation of a Portable Electronic Visual Acuity System." Journal of Mobile Technology in Medicine, vol. 3, no. 2, 2014, pp. 35-39, doi:10.7309/jmtm.3.2.6.

[31] Zhang ZT, Zhang SC, Huang XG, Liang LY. "A Pilot Trial of the IPad Tablet Computer as a Portable Device for Visual Acuity Testing." Journal of Telemedicine and Telecare, vol. 19, no. 1, 2013, pp. 55-59, doi:10.1177/1357633X12474964

[32] Xu R, Bradley A. "IURead: A New Computer-Based Reading Test." Ophthalmic and Physiological Optics, vol. 35, no. 5, Blackwell Publishing Ltd, Sept. 2015, pp. 500-13, doi:10.1111/OPO.12233.

[33] Noyes J, Garland K. "Computer- vs. Paper-Based Tasks: Are They Equivalent?" Ergonomics, vol. 51, Oct. 2008, pp. 1352-75, doi:10.1080/00140130802170387.

[34] Köpper M, Mayr S, Buchner A. "Reading from Computer Screen versus Reading from Paper: Does It Still Make a Difference?" Ergonomics, vol. 59, no. 5, May 2016, pp. 615-32, doi:10.1080/00140139.2015.1100757.

[35] Kang Y-Y, Wang M-JJ, Lin R. "Usability Evaluation of E-Books.' Displays, vol. $30, \quad$ no. 2, 2009, pp. 49-52, doi:https://doi.org/10.1016/j.displa.2008.12.002.

[36] Black JM, Jacobs RJ, Phillips G, et al. "An Assessment of the IPad as a Testing Platform for Distance Visual Acuity in Adults." BMJ Open, vol. 3, no. 6, 2013, pp. 5-7, doi:10.1136/bmjopen-2013-002730

[37] Syed ST, Gerber BS, Sharp LK. "Traveling towards Disease: Transportation Barriers to Health Care Access." Journal of Community Health, vol. 38, no. 5, Oct. 2013, pp. 976-93, doi:10.1007/s10900-013-9681-1.

[38] Alotaibi M, Honarvar Shakibaei Asli B, Khan M. "Non-Invasive Inspections: A Review on Methods and Tools." Sensors (Basel, Switzerland), vol. 21, no. 24, MDPI, Dec. 2021, p. 8474 doi: $10.3390 / \mathrm{s} 21248474$

[39] Khurana RN, Hoang C, Khanani AM, Steklov N, Singerman LJ. “A Smart Mobile Application to Monitor Visual Function in Diabetic Retinopathy and Age-Related Macular Degeneration: The CLEAR Study." American Journal of Ophthalmology, vol. 227, 2021, pp. 222230, doi:10.1002/CENTRAL/CN-02299011. 
[40] Naidoo KS, Leasher J, Bourne RR, et al. "Global Vision Impairment and Blindness Due to Uncorrected Refractive Error, 1990-2010." Optometry and Vision Science, vol. 93, no. 3, 2016, pp. 227-34, doi:10.1097/OPX.0000000000000796. 